\title{
COVID-19: the Potential Role of Nutritional Deficiencies, Global Climatic Changes, and Immune System Dysfunction
}

\section{ART ICLE INF O}

\section{Article Type}

Systematic Review

\section{Authors}

Abdolahi S. ${ }^{1} \mathrm{PhD}$,

Gorji A. ${ }^{* 2} M D$

How to cite this article
Abdolahi S, Gorji A. COVID-19:
the Potential Role of Nutritional
Deficiencies, Global Climatic
Changes, and Immune System Dysf-
unction. Iranian Journal of War \&
Public Health.2020;12(4):249-258.

${ }^{1}$ Shefa Neuroscience Research Center, Khatam Alanbia Hospital, Tehran, Iran

${ }^{2}$ Department of Neuroscience, Faculty of Medicine, Mashhad University of Medical Sciences, Mashhad, Iran

\section{*Correspondence}

Address: Mashhad University of Medical Sciences, Mashhad, Iran. Postal Code: 9177948564.

Phone: +98 (513) 8002477

Fax: +98 (513) 8828560

gorjial@uni-muenster.de

\section{Article History}

Received: September 02, 2020

Accepted: November 28, 2020

ePublished: March 03, 2021

\section{A B S T R A C T}

Aims Climate change may weaken the human immune system. Nutrient deficiency also reduces the ability to fight infections, which is a major cause of immune system deficiencies. Climate change influences food security and, in turn, enhances the prevalence of malnutrition globally. The purpose of the present study was to accumulate evidence indicating the role of climate changes, food insecurity, and weakened immune systems in the COVID-19 pandemic. Information \& Methods This review study was conducted using the keywords. Covid-19, pandemics, epidemics, climate change, micronutrients, the immune system, and a search for domestic and international databases.

Findings Significant associations were found between the unpredictable occurrence of new zoonotic pathogens and reduced immunity, micronutrient malnutrition, and global climate crisis.

Conclusion Lack of integrative health care strategies may play a major role in viral epidemics. The evidence indicates that climate change and food shortage can debilitate the immune system and increase the risk of new epidemics.

\section{Keywords Virus Diseases; Covid-19; Food Supplies; Global Warming; Immune System Disorder}

\section{I T A T I O N L I N KS}

[1] Disease X: Accelerating ... [2] Evidence based management ... [3] COVID-19 pandemic: the ... [4] The potential roles of ... [5] 10 years on, the world ... [6] Host nutritional status ... [7] An integrated assessment ... [8] The impact of climate change ... [9] COVID-19 is possibly a consequence ... [10] High basal heat-shock protein ... [11] Changes in extreme events .. [12] Impacts of drought ... [13] Five lessons from COVID-19 ... [14] Climate change impacts ... [15] Micronutrients and host resistance ... [16] Climate change and nutrition ... [17] New York: Statista; 2020 ... [18] Association between solar ... [19] The possible roles ... [20] Role of fat-soluble vitamins ... [21] Role of vitamin A in the ... [22] Effects of vitamin ... [23] Middle East respiratory ... [24] Immune function and ... [25] Metabolism of dietary and ... [26] The effects of vitamin B on ... [27] Vitamin B5 reduces bacterial ... [28] Micronutrient deficiencies are ... [29] A system of protein target ... [30] Vitamin C and immune ... [31] Vitamin C: An essential "stress ... [32] IL-4 derived from non-T cells ... [33] The protection potential ... [34] 1alpha,25-Dihydroxyvitamin ... [35] Vitamin D increases ... [36] Release of severe acute ... [37] Vitamin D and mortality ... [38] Can supplementation with ... [39] The role of vitamin E ... [40] Vitamin E supplementation ... [41] Relationship between the ... [42] Antioxidant and anti-inflammatory ... [43] Serum zinc and pneumonia ... [44] Crystal structure of Middle ... [45] Selenium, immune function ... [46] Review: Micronutrient selenium ... [47] Glutathione peroxidase protects ... [48] An increase in selenium intake improves ... [49] The effect of iron deficiency ... [50] Hepatitis B virus infection ... [51] Cell iron status influences ... [52] Antiviral effects of ferric ... [53] Iron oxide nanoparticles based ... [54] A review of micronutrients ... [55] Copper and ... [56] Deactivation of human ... [57] Human coronavirus 229E remains ... [58] A role for iodide and ... [59] Extrathyroidal iodide concentrating ... [60] Enhancement of respiratory ... [61] In vitro bactericidal and ... [62] Influence of a complex ... [63] Vitamin A supplementation was ... [64] Drugmicronutrient interactions ... [65] Antibiotic consumption and resistance ... [66] Mutations in the cardiac myosin ... 
طى جند ماه كذشته، كوويد-19 بهعنوان تهديد سلامت عمومى در سراسر جهان ظاهر شده است. ظهور اين ويروس منجر به واكنش

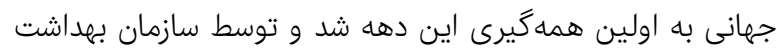

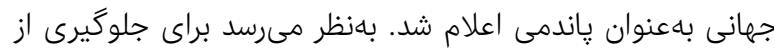

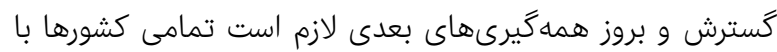

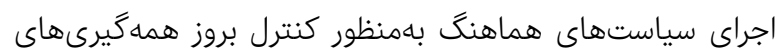

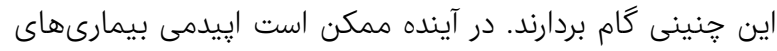

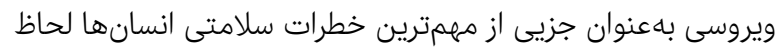

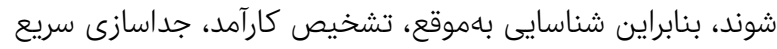

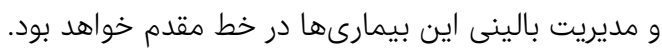

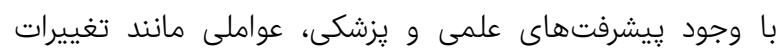
اقليمى، رشد جمعيتها، مهاجرت انسانها، شهرنشينى، ترديد در

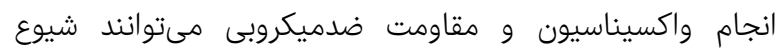
بيمارىها را در آينده بهطور فزايندهاى دشوار كند [3].

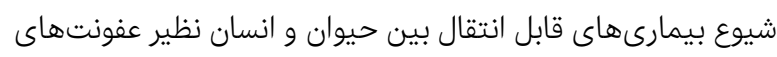

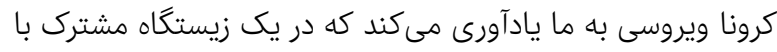

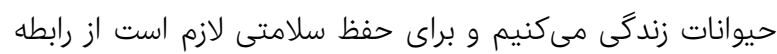

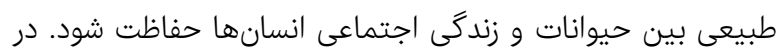
اكوسيستمهاى موجود در طبيعت گونههاى متنوع حيوانى فضاى كافى براى جمعيت حيوانات سالم را دارند. علاوهبر اين، اين

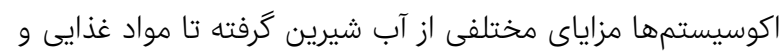

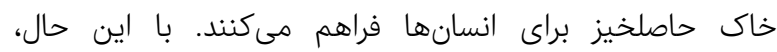

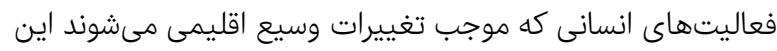
اكوسيستمها را مختل مى كند، بهطورى كه حيوانات بهدنبال كاهش انه

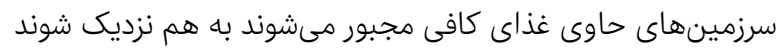

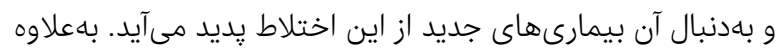

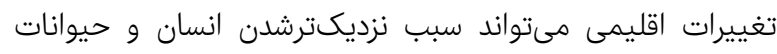

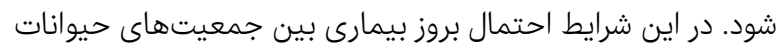

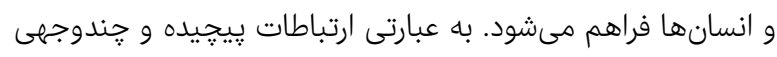

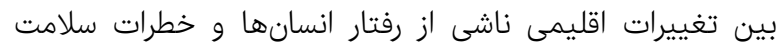

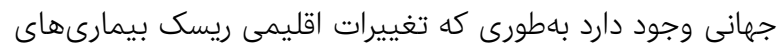

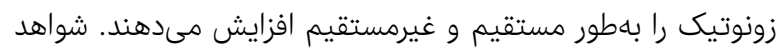

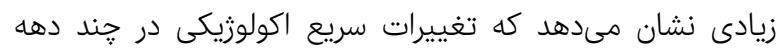

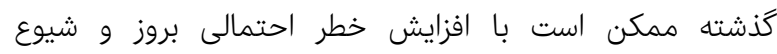

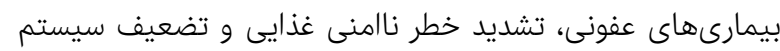

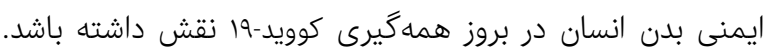

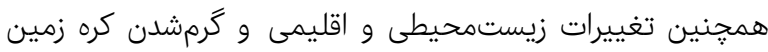

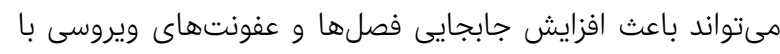

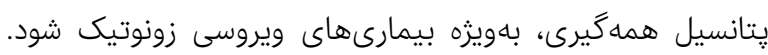

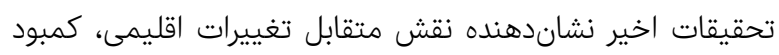

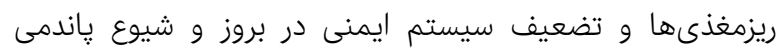

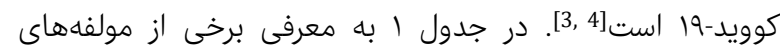
تغييرات زيستمحيطى در بروز بيمارىهاى عفونى يرداخته شده

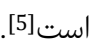

كوويد-19: نقش بالقوه كمبود ريزمغذىها، تهان تغييرات اقليمى جهانى و اختلال عملكرد سيستم ايمنى

سارا عبدالهى PhD

مركز تحقيقات علوم اعصاب شفا، بيمارستان خاتم الانبياء، تهران، ايران

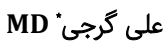

كَروه علوم اعصاب، دانشكده يزشكى، دانشعاه علوم يزشكى مشهد، مشهد، ايران

جكيده

اهداف: تغييرات آب و هوايى ممكن است سيستم ايمنى بدن انسان را تضعيف

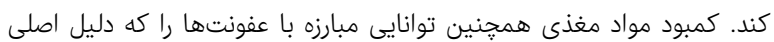

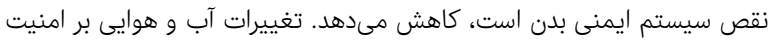

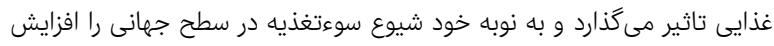

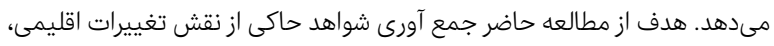

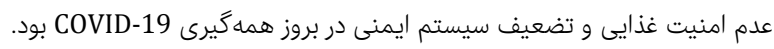

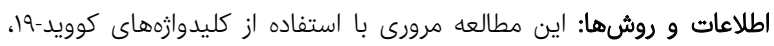

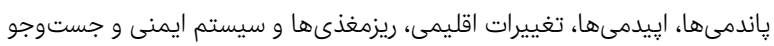

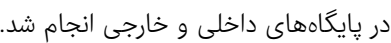

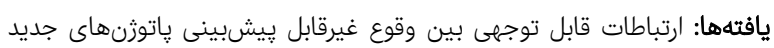

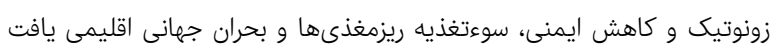

نتيجه گيرى: فقدان راهكارهاى مراقبتهاى بهداشتى يكيارجه ممكن است كه

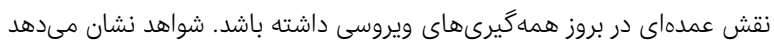

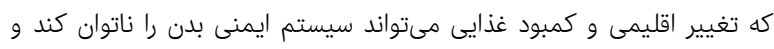

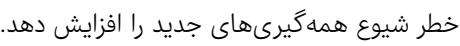

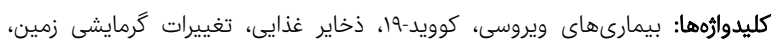

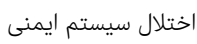

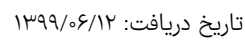

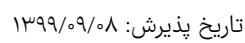
نويسنده مسئول: gorjial@uni-muenster.de

مقدمه

تحقيقات انجامشده در جند دهه گذشته نشان مىدهد كه شيوع

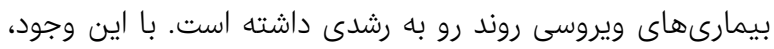

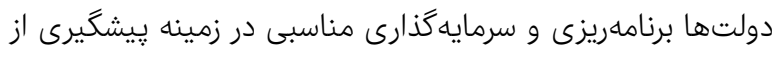

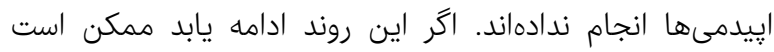

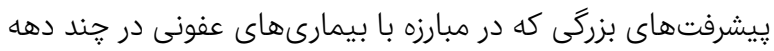

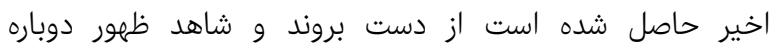

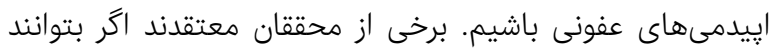

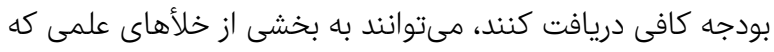

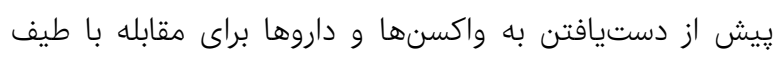
وسيعى از تهديدهاى ويروسى وجود دارد، دست يابند [1].]

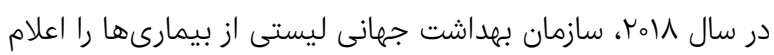
كرد كه تحقيقات در زمينه ييشگيرى و درمان آنها در اولويت قرار

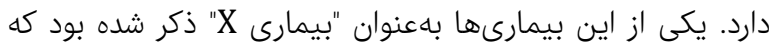

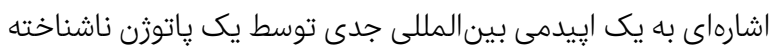

داشت[2]. 
كوويد-19: نقش بالقوه كمبود ريزمغذىها، تغييرات اقليمى جهانى و اختلال عملكرد سيستم ايمنى الما

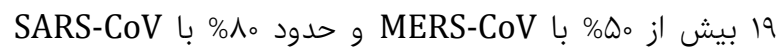

شباهت دارد[3]. سيستم ايمنى ذاتى بهعنوان اولين خط دفاعى بدن سبب مهار مار تكثير

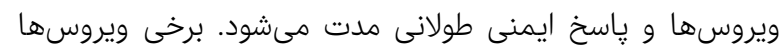

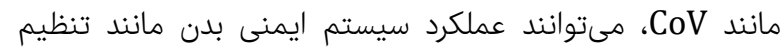

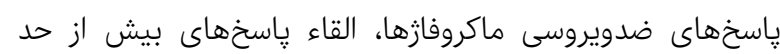

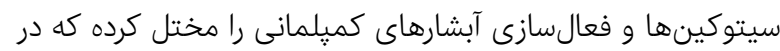

نهايت ممكن است منجر به يك عفونت شديد شوند [4].

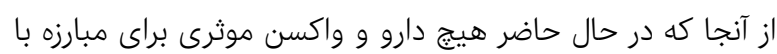
كوويد-19 وجود ندارد، تقويت سيستم ايمنى بدن داضن هـاتواند كزينه

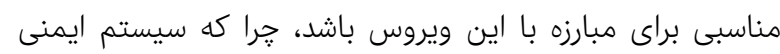

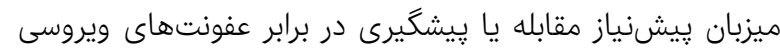

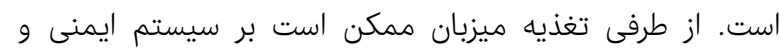

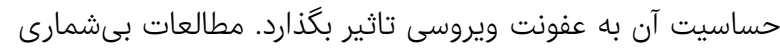

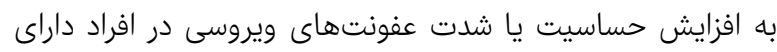

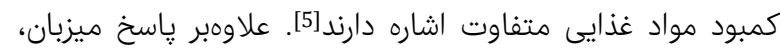
ريزمغذىهاى مختلف با تاثير بر روندهايى كه در فرآيندهاى مداى

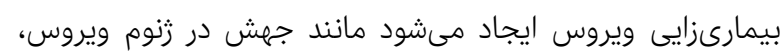

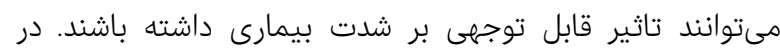

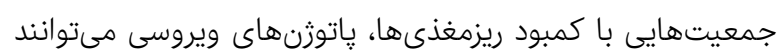

به سويههاى جديد با بيمارىزايى شديدتر تبديل شوند [6].

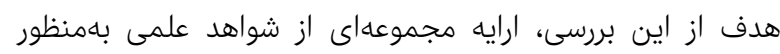

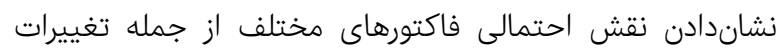

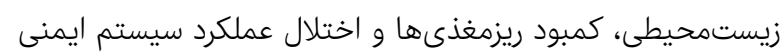
در تعامل بين سيستم ايمنى بدن ميزبان و ويروسهانها، بهويزه كرونا ويروس است.

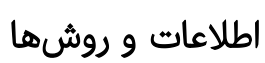

مطالعه حاضر مرورى يكيارجه است كه طى جستوجوى منات متون و

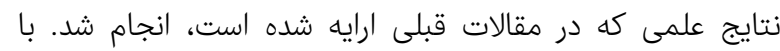

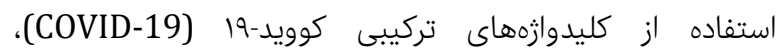

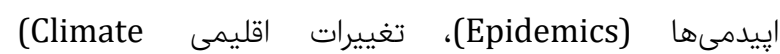

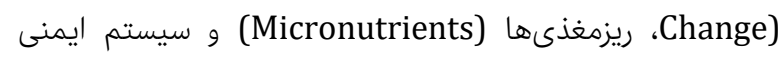
اقدام به جستوجو در پايگاههاى بين المللى (Immune system) Google Scholar PubMed ،Science Direct ،Springer

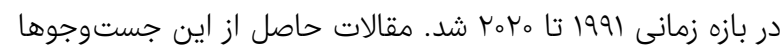

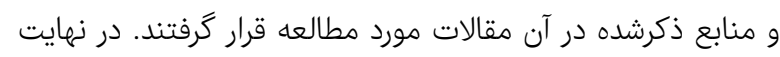

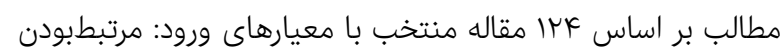

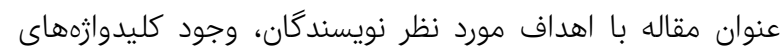

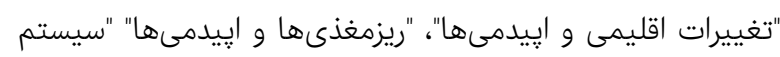

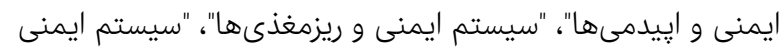

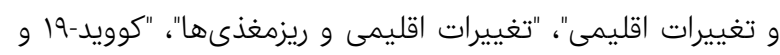

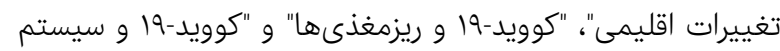
ايمنى" در متن مقاله جمعبندى شد. اولويت مطالعات يزوهشى،

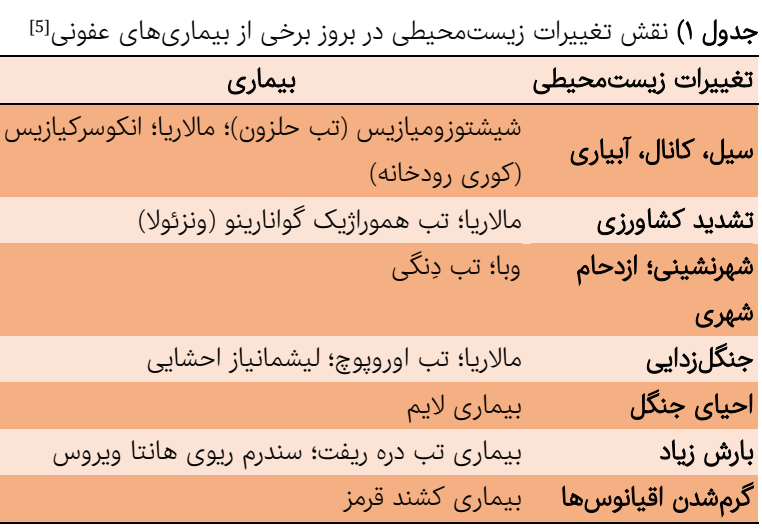

إييدمىها يكى از دشمنان سرسخت، ماندگًار و كشنده تاريخ بشر

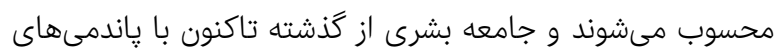

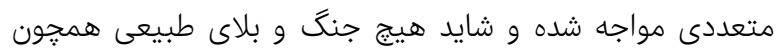

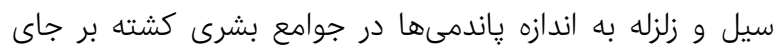

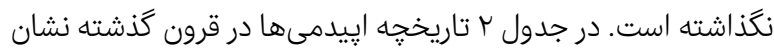

داده شده است.

جدول r) تاريخجه إيبدمىها در قرون كذشته

\begin{tabular}{|c|c|c|}
\hline سال & بيمارى & تخمين مرگومير \\
\hline م1/170 پِيشاز ميلاد & طاعون آنتونين & 0 \\
\hline$|\mu \varepsilon \gamma-| \mu 0 \mid$ & طاعون سياه & roo ميليون Ro \\
\hline 10ro & آبله & 07 ميليون \\
\hline 1700 & طاعون بزرگ (قرن IV) & س ميليون \\
\hline IVoo & طاعون بزرگ (قرن \/) & (700 هزار \\
\hline INIV-19YK & 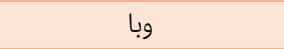 & ا ميليون \\
\hline 1 & ت تب زرد & ما10-100 هزار \\
\hline $191 \lambda-1919$ & آنفولانزاى اسِيانيايى & 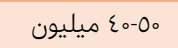 \\
\hline $1 \wedge \wedge 9-1 \wedge 9$. & آنفولانزاى روسى & ا ميليون \\
\hline $190 V-1901$ & آنفولانزاى آسيايى & 1/ا ميليون \\
\hline $1971-19 \mathrm{~V} 。$ & آنفولانزاى هنگ كنگى & ا ميليون \\
\hline 1911 & ايدز & مس-or ميليون \\
\hline$r_{\circ \circ Y-Y_{0 \circ} \mu}$ & سندرم حاد تنفسى (سارس) & ل هزار VV。 \\
\hline$r_{009-r_{0}}$ & آنفولانزاى خوكى & 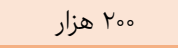 \\
\hline$r_{0}\left|\varepsilon-r_{0}\right| \tau$ & ابولا & > > || هزار \\
\hline$r .10$ & $\begin{array}{c}\text { سندرم تنفسى خاورميانه } \\
\text { (مرس) }\end{array}$ & 10。 هزار \\
\hline r.19 & كوويد-19 & ل هزار VII \\
\hline
\end{tabular}

كرونا ويروسها (CoV) گروه بزرگى از ويروسهاى RNA

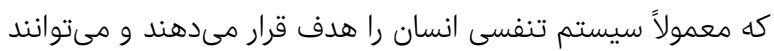

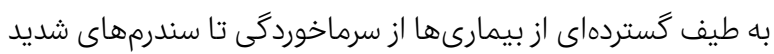

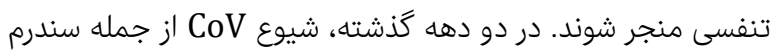

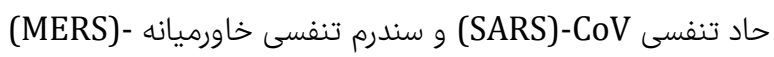

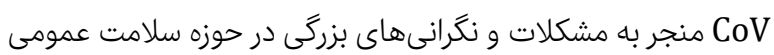

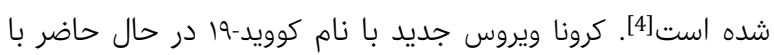
افزايش تعداد و ميزان عوارض و تلفات همراه است. تجزيه و و تحليلهاى زنتيكى نشان داده است كه توالى زنوم ويروس كوويد- 
مهمى در تكثير، توسعه و سرعت انتقال پاتوثنهاى ويروسى دارند،

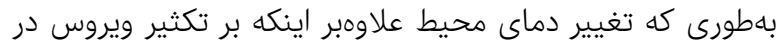

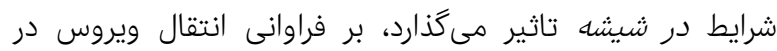

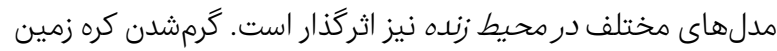

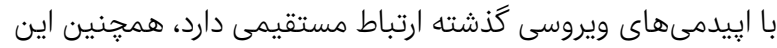

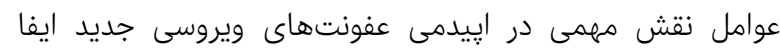

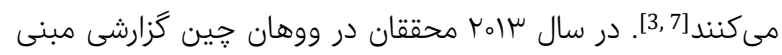

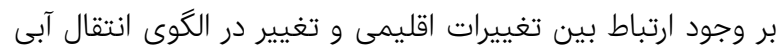
و هوايى بيمارىهاى عفونى، منتشر كردند در اين مطالعات

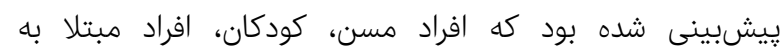

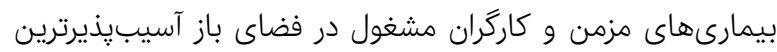

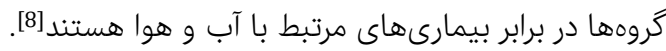
تاثير تغييرات اقليمى بر زندگى جانداران

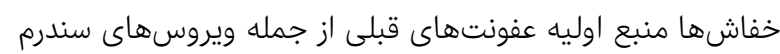

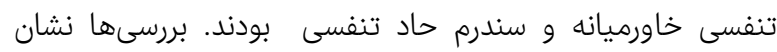
مىدهد كه خفاشها ممكن است مظنون اصلى بهاعنوان ميزبان

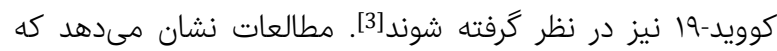

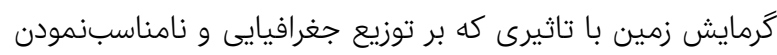

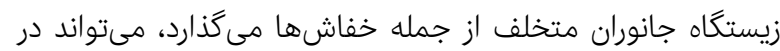

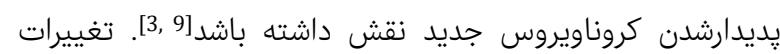

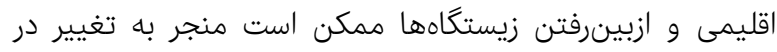

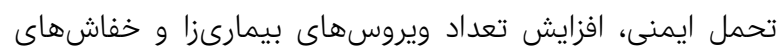

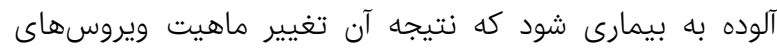

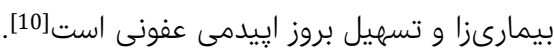

\section{رخدادهاى زيستمحيطى و كوويد-19}

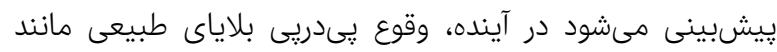

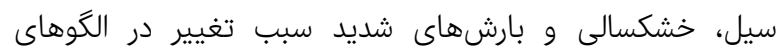

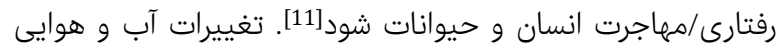
و افزايش شهرنشينى سبب كاهش گسترده مناطق تالابى در ووهان קين شد كه اين مساله با محدودشدن توليد مواد غذايى همراه شده

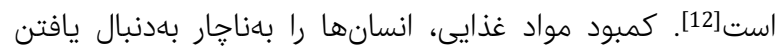

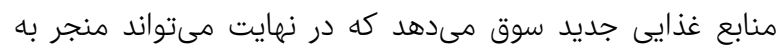

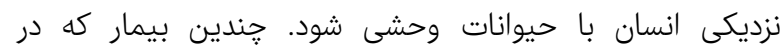

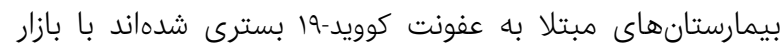

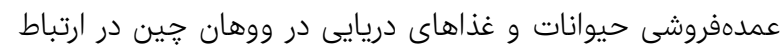

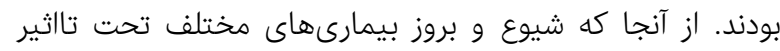

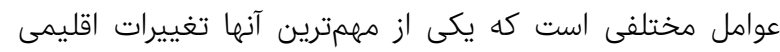

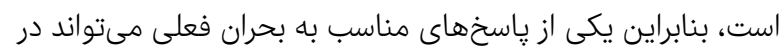

كرو رفع مشكلات تغييرات اقليمى باشد [3.13). تغييرات اقليمى و امنيت غذايى

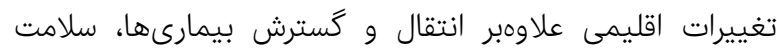

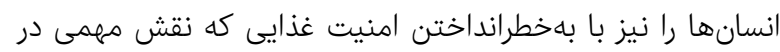

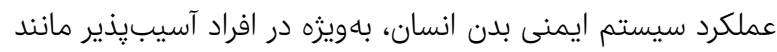

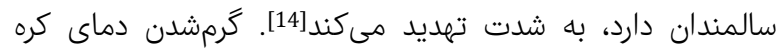

مقالات جابشده در مجلات معلى معتبر علمى و مقالات با دسترسى كامل

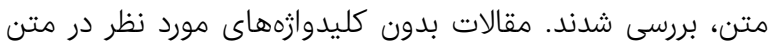

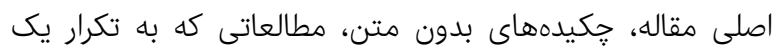

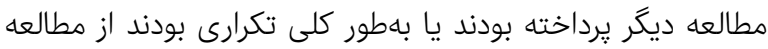

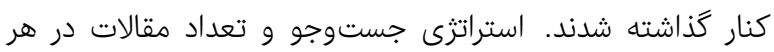

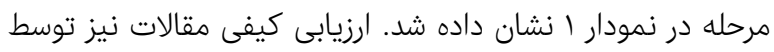

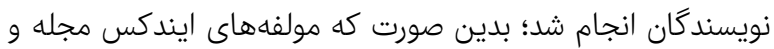

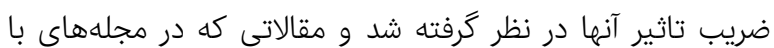
ايندكس و ضريب تاثير بالاتر بودند انتخاب شدند
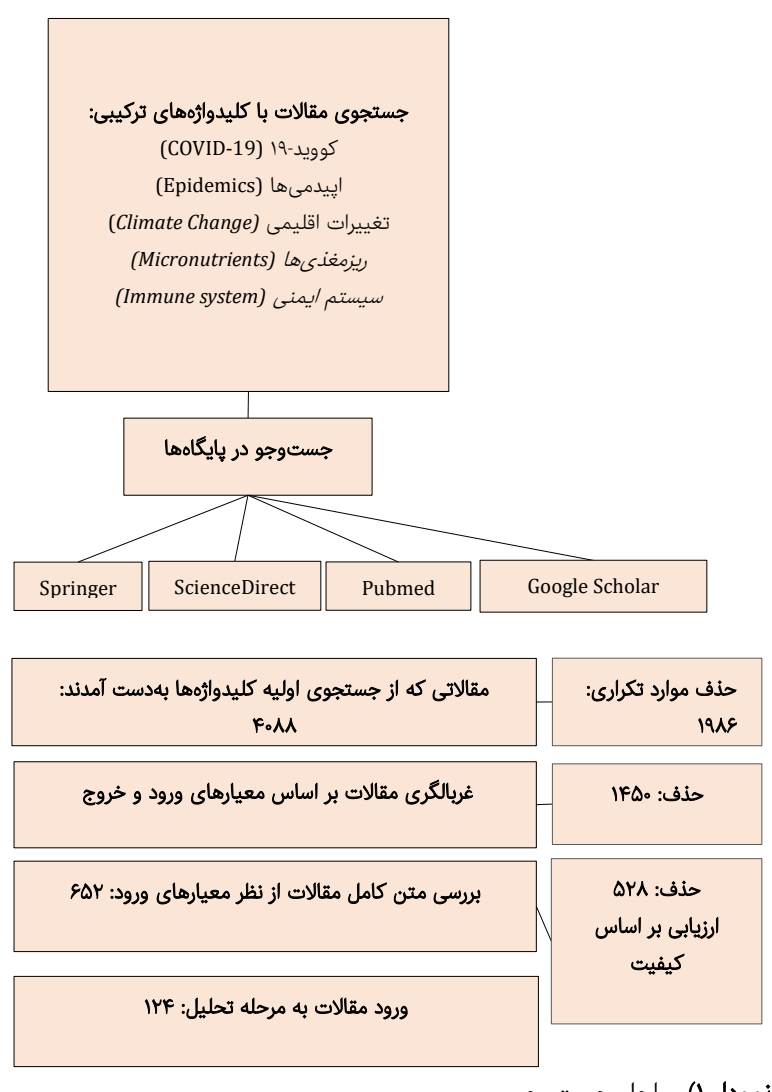

يافتهها

در اين مطالعه به بررسى مقالات مرتبط با تغييرات اقليمى و نقش

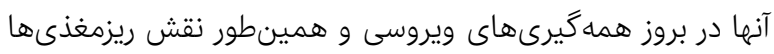

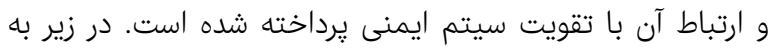

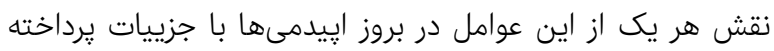

شده است.

\section{تغييرات اقليمى و بيمارىهاى ويروسى لتره}

ييشنهادهاى علمى متعددى نشان داده است كه تغييرات اقليمى ونى

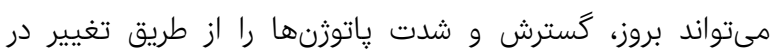

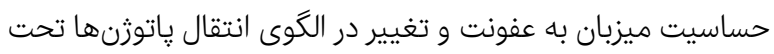

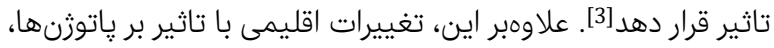

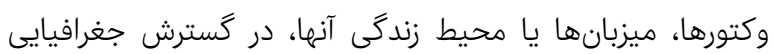

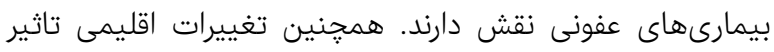




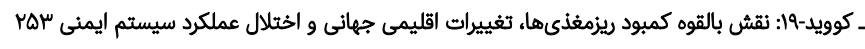
نشان مىدهند كه ويتامين A تنظيمكننده اصلى ايمنى مخاطى تلى

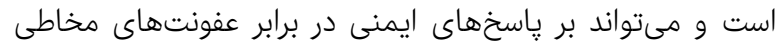

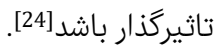
ويتامين B: ارتباط قوى بين ويتامينهاى B و ياسخ ايمنى ميزبان

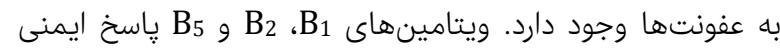

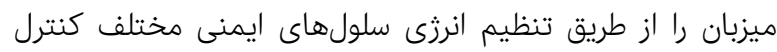

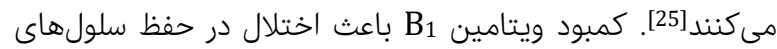

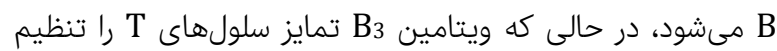
مىكند و در كاهش سيتوكينهاى التهابى و بيان ثن

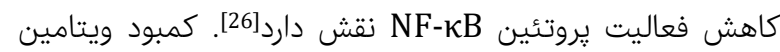
از ط5 طريق توليد بيشتر واسطههاى التهابى در افزايش التهاب

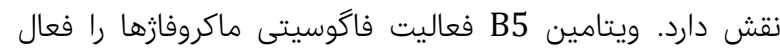

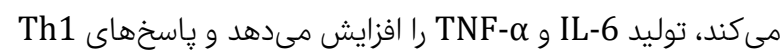

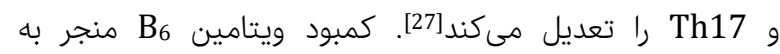

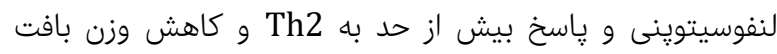

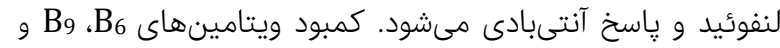
افراد را در معرض عفونتهاى تنفسى ويروسى مانند آنفولانزا

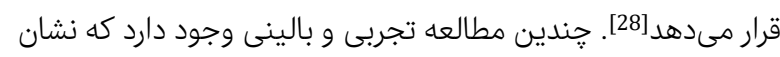

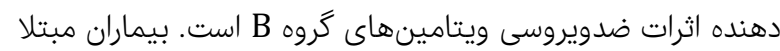

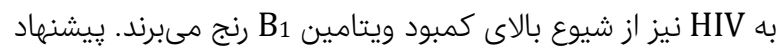

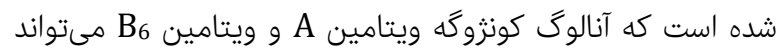
با تنظيم رونويسى ويروسهاى مختلف RNA از جمله كرونا ويروسها، اثر ضدويروسى داشته باشد [29].

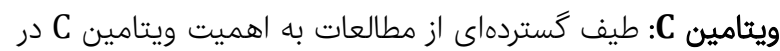

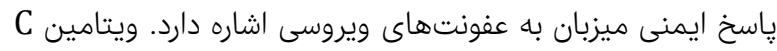

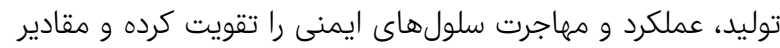

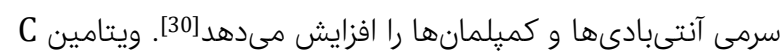

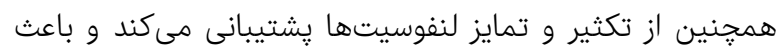

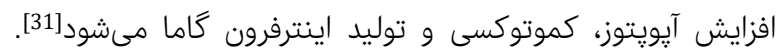

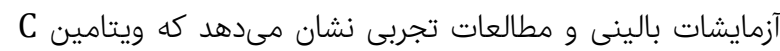

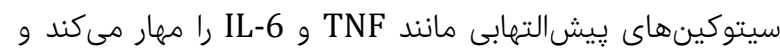
باعث افزايش سيتوكينهاى التهابى مانند TNF، IL-6 و و مىشود. ويتامين C از طريق تقويت توليد IFN-IL-1 ياسخ ايمنى ضدويروسى در برابر ويروس آنفولانزا مىشود [32]. تحقيقات متعددى نشان دادهاند كه ويتامين C در دوزهاى زئن زياد،

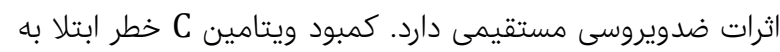

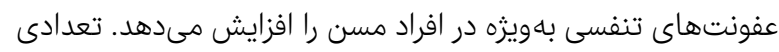

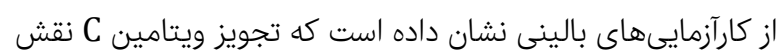
ARDS (Acute Respiratory موثرى در بهبود بيمارن Distress Syndrome) ويتامين D: ويتامين D بهطور فعال در تنظيم رِاسخهاى ايمنى

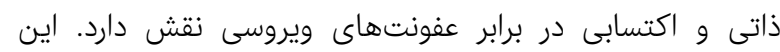

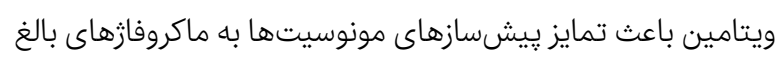

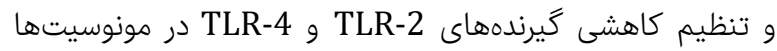

زمين، سطح آلودگى هوا را افزايش مىدهد كه ميزان دسترسى و

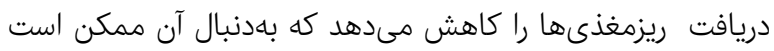
تغييراتى در تركيب زنتيكى ويروسها ايجاد شود كه منجر به ظهور

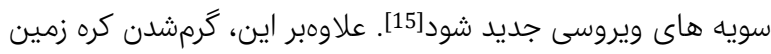

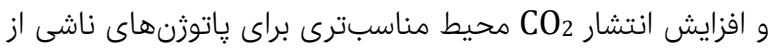

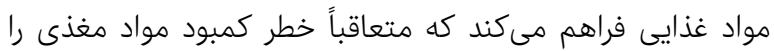
افزايش مىدهد [16]. بهطور كلى كمبود ريزمغذىها و عملكرد سيستم ايمنى بدن بر بر بروز و نتيجه كلى عفونتهاى ويروسى تاثيرگذار است. باعنوان مثال،

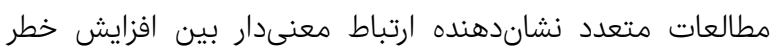

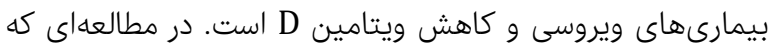
در سال roro انجام شد، مشخص ويروسى شد كه منطقه لومباردى كه كانون

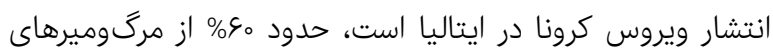

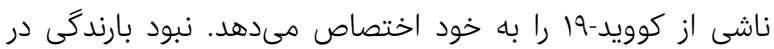

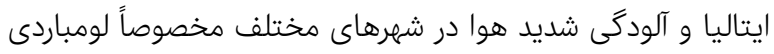

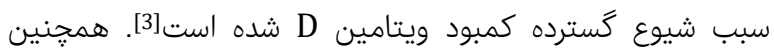

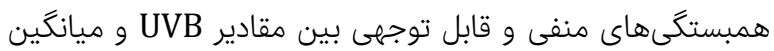

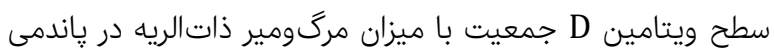

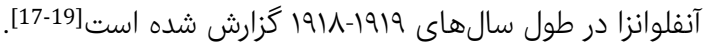

\section{ريزمغذىها و اثر متقابل ڤاسخ ايمنى و ويروسها}

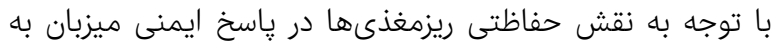

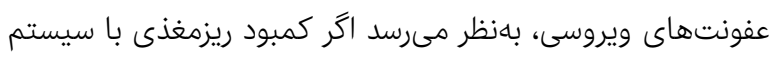

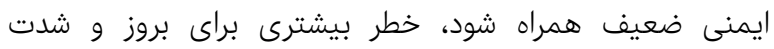

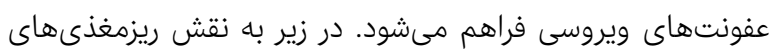
مختلف در بروز و شيوع بيمارىهاى ويروسى با جزييات يرداخته شده است. ويتامين A: مطالعات مختلف نقش ويتامين A را در پاسخهاى

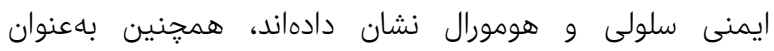

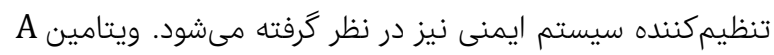

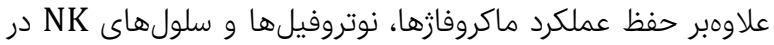

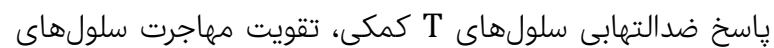
CD+8 نقش دارد[4, 20]. كمبود ويتامين A A سلولهاى T واسطهاى، كاهش تكثير لنفوسيتها و افزايش اتصال

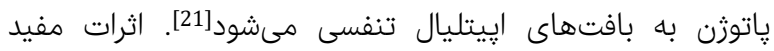

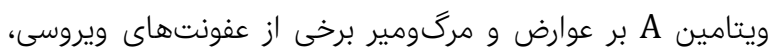

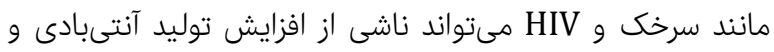
Tكثير لنفوسيتها و همجنين افزايش لنفويوئيزيس سلولهاى

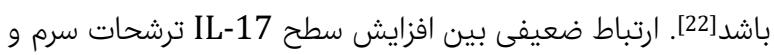

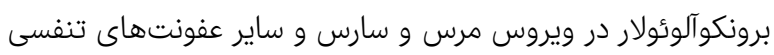

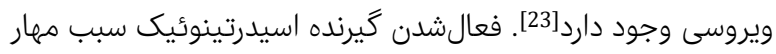
توليد سلولهاى Th17 و همجنين توليد سيتوكين التهابى كليدى فردي از جمله IL-17 مىشود، از طرفى در تقويت خاصيت ضدالتهابـ سلولهاى T نقش دارد. بررسىهاى بالينى و مطالعات آزمايشگاهى 
روى: هموستاز روى براى حفظ عملكرد مناسب سيستم ايمنى ضرورى است. روى بهدليل تاثير بر سنتز و ترميم اسيدنوكلئيك، آيويتوز، التهاب و هموستاز ردوكس، نقش مهمى در برهم بهنش

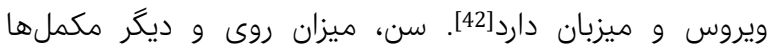

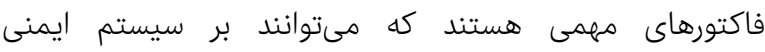

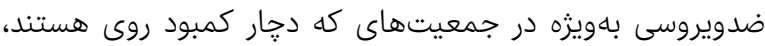

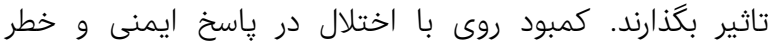

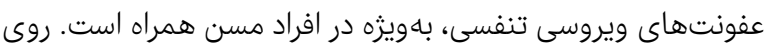
با هدف قراردادن NF-кB در كاهش ياسخ ضد التهابى نقش دارد. از

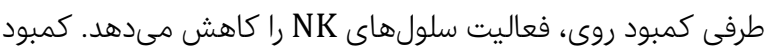
روى از طريق تغيير عملكرد و تعداد سلولهاى ايمنى منجر به

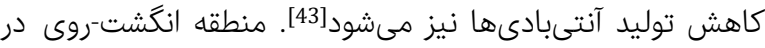
SARS- ها، مانئن CoV

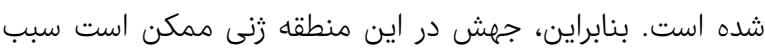

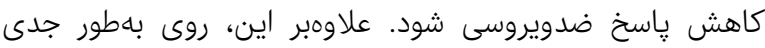

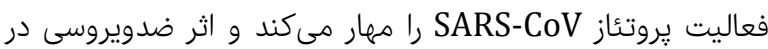
CoV-229E

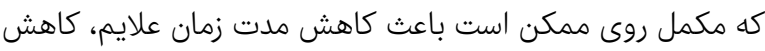

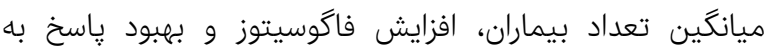
ايمونوترايى در عفونتهاى ويروسى مختلف شود [44].

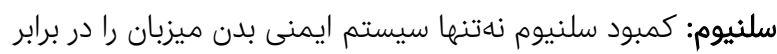
عفونتهاى ويروسى تضعيف مىكند، بلكه منجر به جهش زئه زنوم

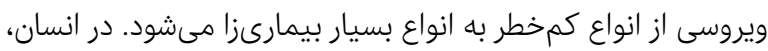

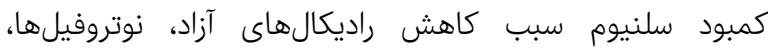

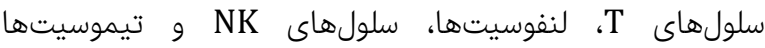

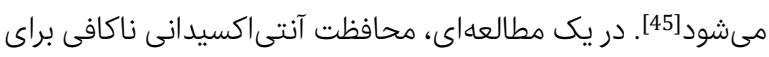

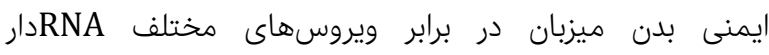
جهشيافته، از جمله SARS-CoV، در افراد با غلظت سلنئن إنيوم خون

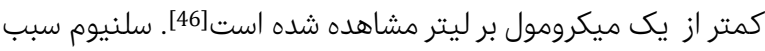

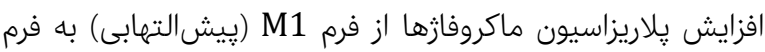
(ضدالتهابى) مىشود. سلنيوم ممكن است اثر ضدالتهابى خود

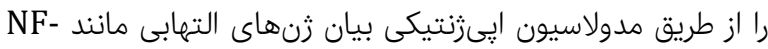

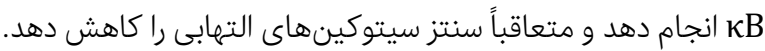
مطالعات بالينى متعددى تاثير مفيد مكمل سلنيوم را در افزايش

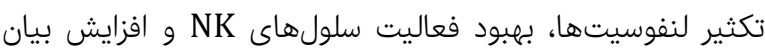

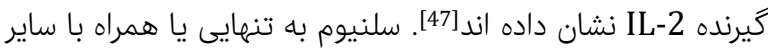

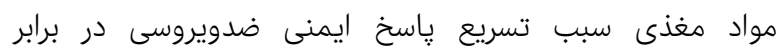

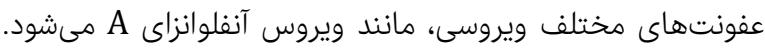

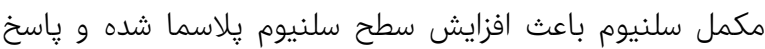

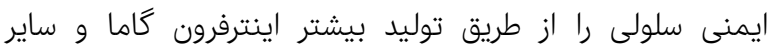

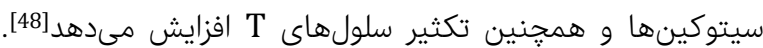
علاوهبر اين، سلنيوم يك كنترل قوى بر بيمارىزايى ويروس دارينئ دارد و

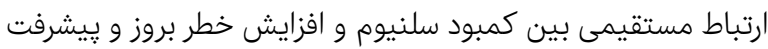

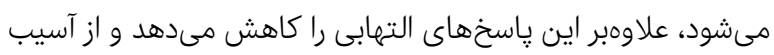

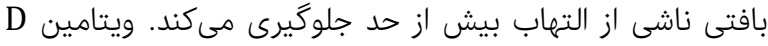

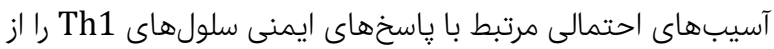

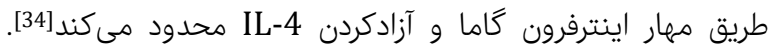

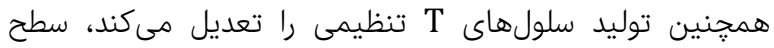
اينترفرون گاما و IL-17 را كاهش مىدهد، ترشح IL-4 و

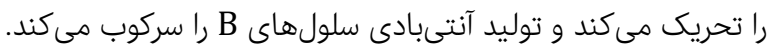
تاثير ويتامين D روى تكثير رينوويروس در دولنيد سلولهاى إييتليال برونشى به احتمال زياد از طريق فعالشدن مسير اينترفرون كَاما است[35]. يكى از تروتئينهاى جانبى SARS-CoV به نام

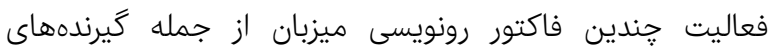

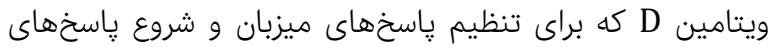

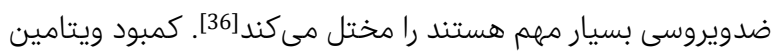

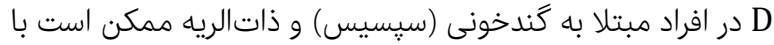
اختلال در عملكرد جندين عضو و حتى مرگُومير همراه باشد. مصرف مكملهاى ويتامين D خطر كلى مرگ خومير را در اين بيماران

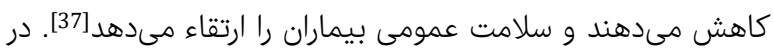

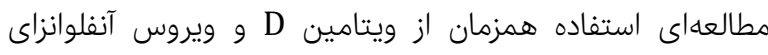
غيرفعال شده سبب افزايش پاسخ آنتىبادى در برابر هموكّلوتينين

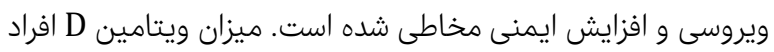

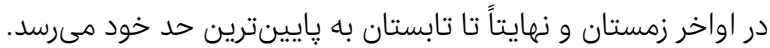

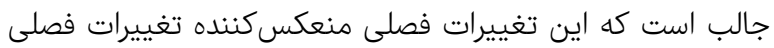

مشخصى از عفونتهاى تنفسى ويروسى و گندخونى است] [38].

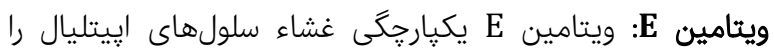
يشتيبانى مىكند. همجنين توليد IL-2، فعاليت سلولهای

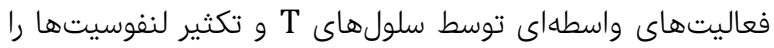
افزايش مىدهد. علاوهبر اين، ويتامين E Eبب فوسئ فعالسازى سلولهاى T، افزايش تكثير سلولهاى Th1 و مهار پراسخ سلولهاى

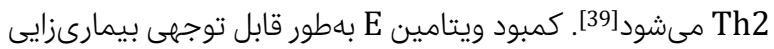

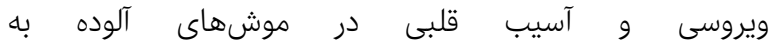
ا افزايش مىدهد. در مطالعهاى Coxsackieviruses-B3

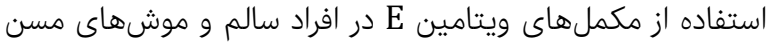

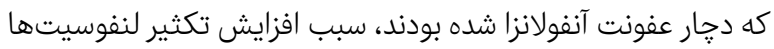

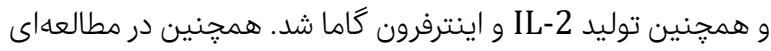
ديكر استفاده از مكملهاى ويتامين E در حيوانات مبتلا به ويروس

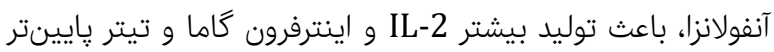

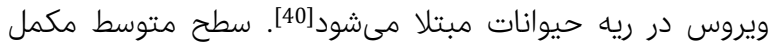
ويتامين E سبب تنظيم تعادل آنتىاكسيدانى راديكال آزاد سلولى و تقويت پاسخ آنتىبادى مىشود. ارتباط مثبتى بين سطح سيتوكين

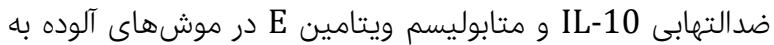
وجود دارد. ويتامين E $\mathrm{H} \mathrm{N}_{1}$ جه ويروسى دارند. در شرايط كمبود تغذيهاى اين ريزمغذىها،

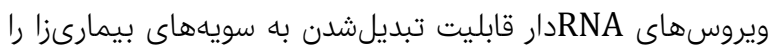

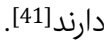


ريزمغذىها، سيستم ايمنى و كوويد-19

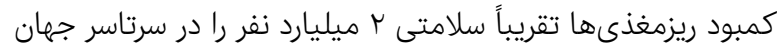

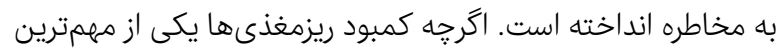

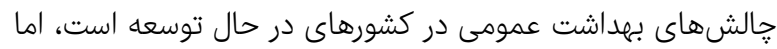

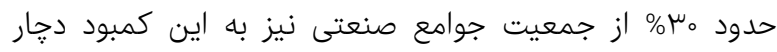

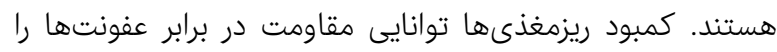
كاهش مىدهد و از دلايل عمده نقص ايمنى در كشورهاى در حال

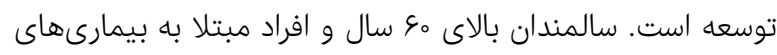

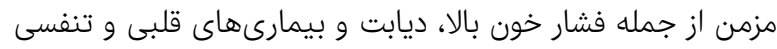

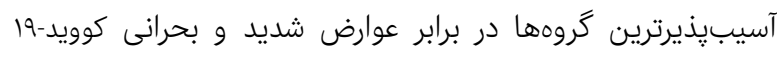

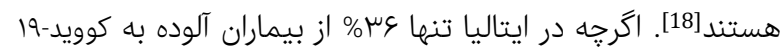

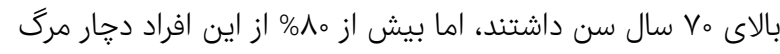

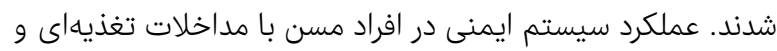
دارويى قابل تغيير است. با افزايش سن تغييراتى درد در سيستم ايمنى مرنى

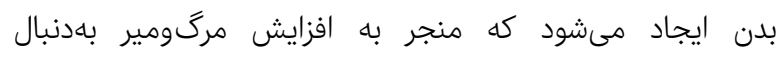
بيمارىهاى عفونى مىشود. اين عملكرد تغييريافته سيستم ايمنى إنى در افراد مسن را مىتوان از طريق دستكارى در توليد سيتوكينها، مئها، تغيير مسيرهاى متابوليكى سلولهاى ايمنى و جوانسازى سيستم ايمنى با هدف فعالسازى لنفوسيتهاى جديد ارتقا داد. مداخلات

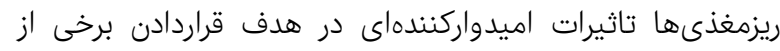

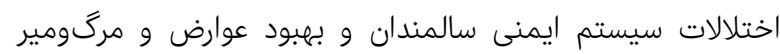

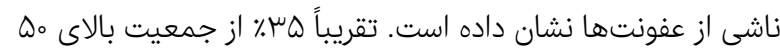

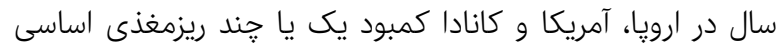

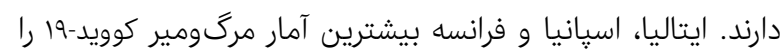

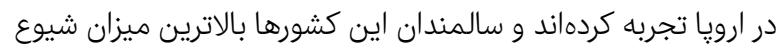

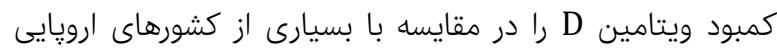

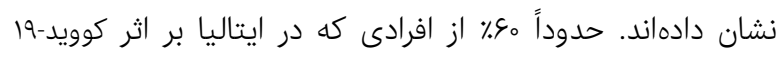

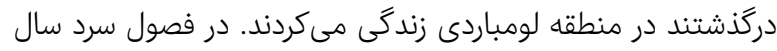

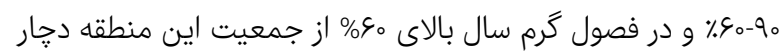

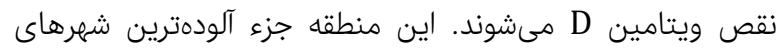

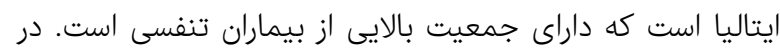

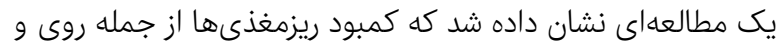
ويتامينها در افراد مسن ساكن اكوادور باعث تضعيف دئ سيستم

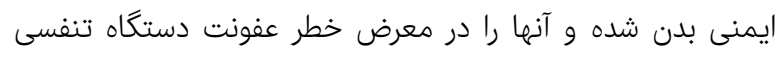

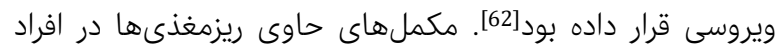

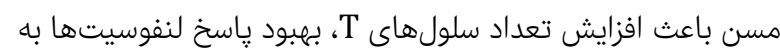

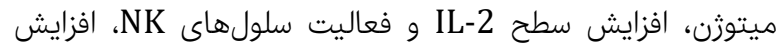

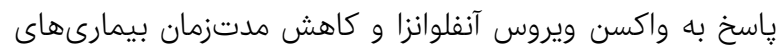

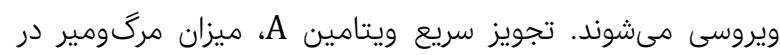

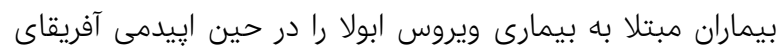

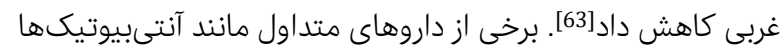

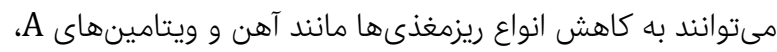

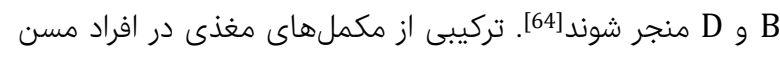

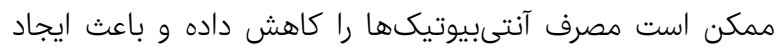

برخى از عفونتهاى ويروسى گزارش شده است[49].

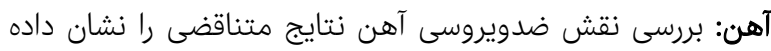

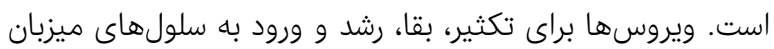

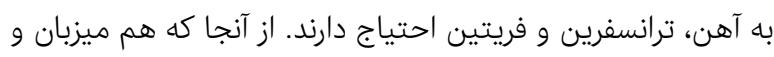

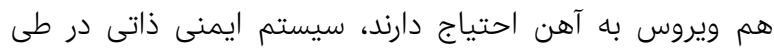

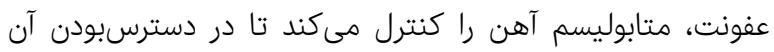
محدود شود. براى دستيابى به يك ياسخ ايمنى مطلوب بائ رايد سطح

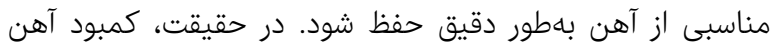
توانايى سيستم ايمنى بدن را در محدودكردن عفونت ويروسى بهوئه اهويزه

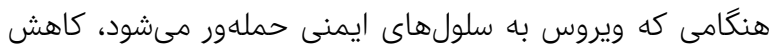

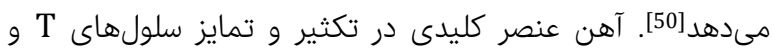
همجنين در تنظيم نسبت بين سلولهاى T كمكى و سيتوتوكسيك

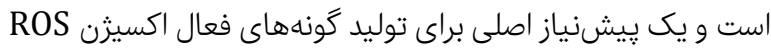
و فعاليت ميلويراكسيداز (Reactive Oxygen Species)

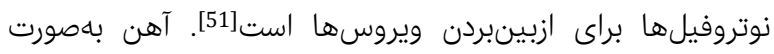

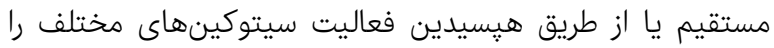

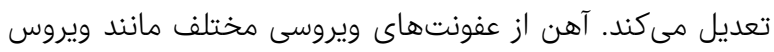

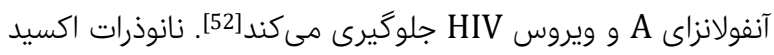

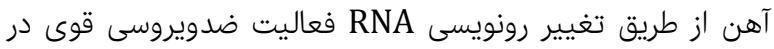

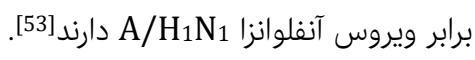
مس: مس ماده مغذى اساسى براى رشد و نكهدارى سيستم ايمنى دراسى

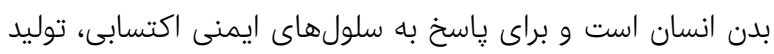

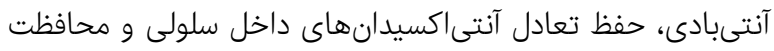

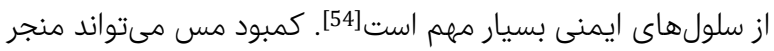

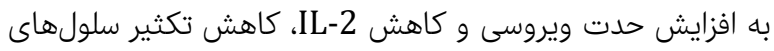

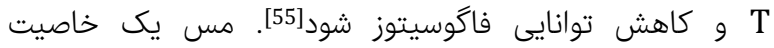

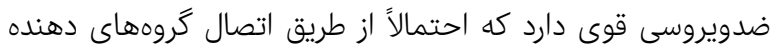
الكترون به يروتئينهاى ويروسى يا اسيدهاى نوكلئيك اتفاق

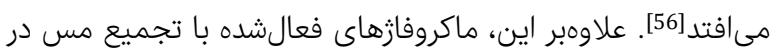

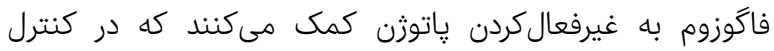

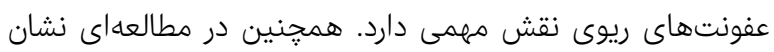

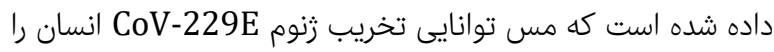

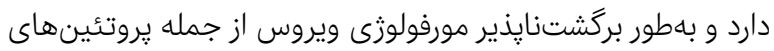

اينولوب ويروس را تغيير مىدهد [57).

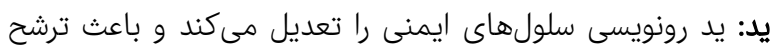

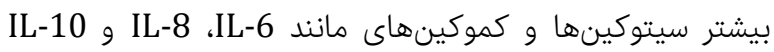

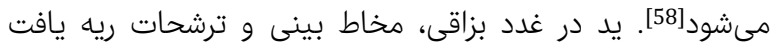

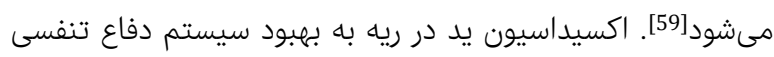

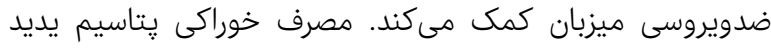
غلظت يد سرم را افزايش داده و منجر به تجمع يد در مائ مايع سطوح

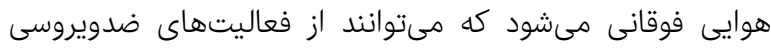

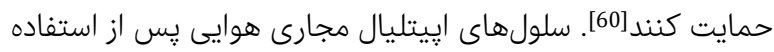

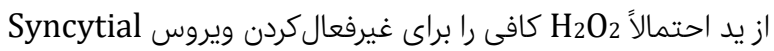
تنفسى از طريق اكسيداسيون گروههاى تيول بهدست مىآورند [61] 
مقرونبهصرفه و بدون عارضه را با نويد فوايد طولانى مدت در شيوع ويروسهاى آينده ارايه دهد.

\section{نتيجه گيرى}

بيمارى ناشى از ويروس كوويد-19 مهمترين مساله امروز بهداشت

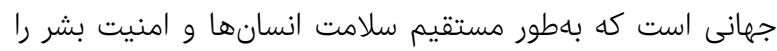

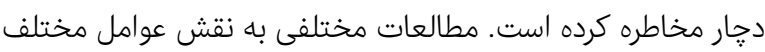
از جمله تغييرات اقليمى، رشد جمعيتها، كمبود مواد غذايى و ومانه كاهش سيستم ايمنى بدن ميزبان در افزايش شيوع بيمارىهاى جيمان

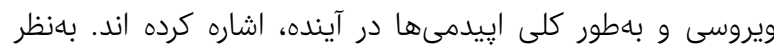

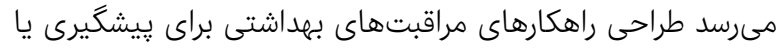

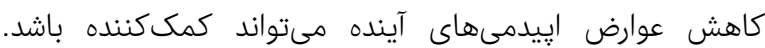

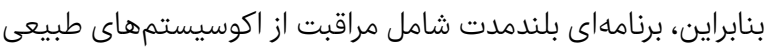

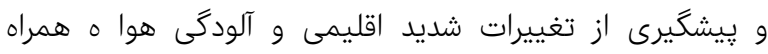
فراهمنمودن ريزمغذىها بهخصوص در افراد مسن و بيماران مبتلا

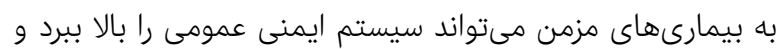

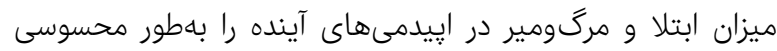

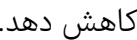

تشكر و قدردانى: بدينوسيله نويسندكان بر خود لازم مىدانند مراتب تشكر

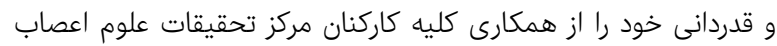

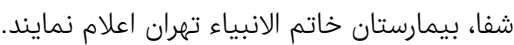

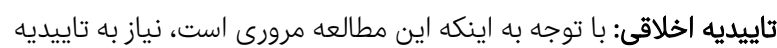

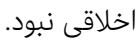
تعارض منافع: بدينوسيله نويسندگًان اعلام مىدارند كه هيج گَونه تضاد منافعى در رابطه با نكارش يا انتشار اين مقاله با يكديكر ندارند.

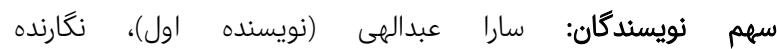

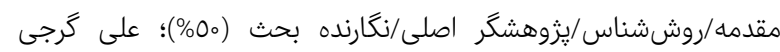

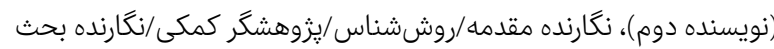

منابع مالى: اين مقاله در مركز تحقيقات علوم اعصاب شفا، بيمارستان

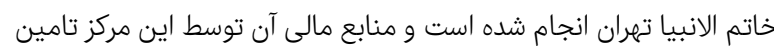

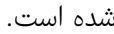

منابع

1- Simpson S, Kaufmann MC, Glozman V, Chakrabarti A Disease X: Accelerating the development of medical countermeasures for the next pandemic. Lancet Infect Dis. 2020;20;e108-15.

2- Nicola M, O'Neill N, Sohrabi C, Khan M, Agha M, Agha R. Evidence based management guideline for the COVID-19 pandemic-review article. Int J Surg. 2020;77;206-16.

3- Gorji S, Gorji A. COVID-19 pandemic: the possible influence of the long-term ignorance about climate change. Environ Sci Pollut Res. 2021;1-5.

4- Gorji A, Ghadiri MK. The potential roles of micronutrient deficiency and immune system dysfunction in COVID-19 pandemic. Nutrition. 2020;111047.

5- Arnold C. 10 years on, the world still learns from SARS. Lancet Infect Dis. 2013;13(5):394-5.

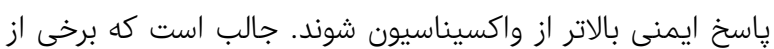
كشورها با عوارض و مرگ لِومير بالاى كوويد-19 مانند ايتاليا و اسيانيا، مصرف بالاترى از آنتىبيوتيكها نسبت به ساير كشورهاى ارويايى

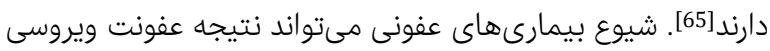

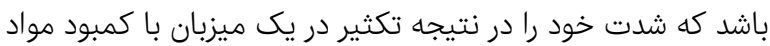

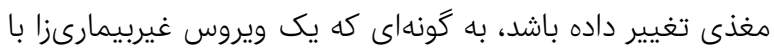
تغيير در زنوم آن بيمارىزا مىشود. ظهور مداوم سويههاى جداس جديد ويروسهاى RNA دار با خصوصيات بيمارىزايى جديد مانند كرونا ويروسها با افزايش نرخ جهش در جمعيت محروم از ريزمغذى

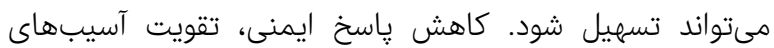

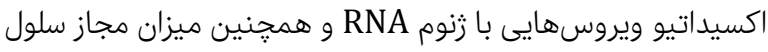

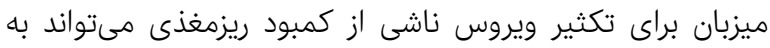
افزايش فرصت جهشهاى ويروسى منجر شود [66].

\section{بحث}

توسعه واكسيناسيونهاى جديد و داروهايى كه ياتوزنهاى مرتبط

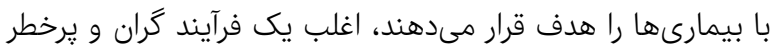

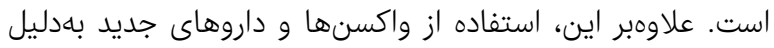
هزينههاى بالا معمولاً در سطح جهانى با محدوديتهايتى آدائ همراه

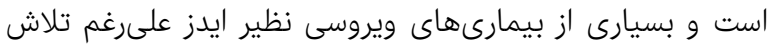

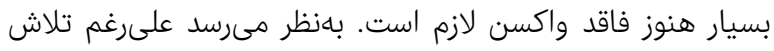

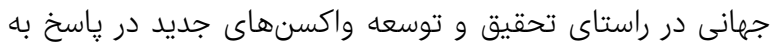

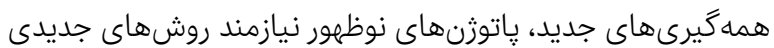
در زمينه طراحى واكسن هستند. مطالعات مختلفى نشان مى هيدهد

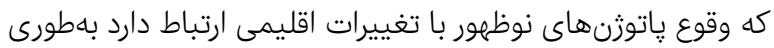

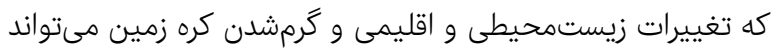
باعث افزايش جابجايى فصلها و عفونتهاى ويروسى با يتانسيل

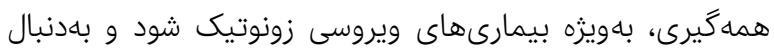
تغييرات اقليمى، كمبود ريزمغذى و در نهايت كاهش ايمنى ديمائ ميزبان

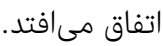
از طرفى، تحقيقات بالينى متعددى در مورد نقش ريزمغذىها در

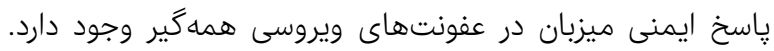
نتايج اين تحقيقات نشان داده است كه كمبود ريزمغذىهان دها در افراد

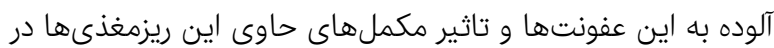

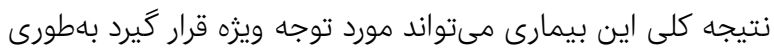

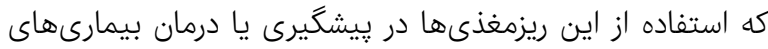
عفونى مانند كوويد-19 مىتواند موثر باشد. علاوهبر اين، نتايج تحقيقات نشان مىدهد كه ارتباطات معنىدارى بين وقوع غيرقابل

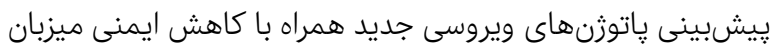

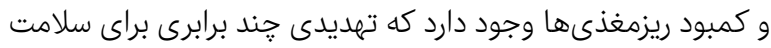

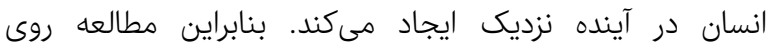

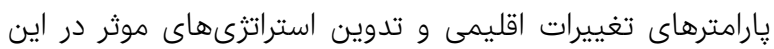
زمينه و همجنين بررسى بيشتر نقش ريزمغذىهارئر و جايكزينى آنها در فعاليت سيستم ايمنى بدن ممكن است يكن ينى اقدام بسيار 
كوويد-19: نقش بالقوه كمبود ريزمغذىها، تغييرات اقليمى جهانى و اختلال عملكرد سيستم ايمنى roV

Microbial Rev. 2015;28(2):465-522.

24- Maggini S, Pierre A, Calder PC. Immune function and micronutrient requirements

change over the life course. Nutrients. 2018;10:1531.

25- Yoshii K, Hosomi K, Sawane K, Kunisawa J. Metabolism of dietary and microbial vitamin $\mathrm{B}$ family in the regulation of host immunity. Front Nutr. 2019;6:48.

26- Mikkelsen K, Stojanovska L, Prakash M, Apostolopoulos V. The effects of vitamin B on the immune/cytokine network and their involvement in depression. Maturitas. 2017;96:58-71.

27- He W, Hu S, Du X, Wen Q, Zhong XP, Zhou X, et al. Vitamin B5 reduces bacterial growth via regulating innate immunity and adaptive immunity in mice infected with Mycobacterium tuberculosis. Front Immunol. 2018;9:365.

28- Hamer DH, Sempértegui F, Estrella B, Tucker KL, Rodríguez A, Egas J, et al. Micronutrient deficiencies are associated with impaired immune response and higher burden of respiratory infections in elderly Ecuadorians. J Nutr. 2009;139(1):113-9.

29- Kesel AJ. A system of protein target sequences for antiRNA-viral chemotherapy by a vitamin B6-derived zincchelating trioxa-adamantane-triol. Bioorg Med Chem. 2003;11(21):4599-613.

30- Ang A, Pullar JM, Currie MJ, Vissers MC. Vitamin C and immune cell function in inflammation and cancer. Biochem Soc Trans. 2018;46(5):1147-59.

31- Marik PE. Vitamin C: An essential "stress hormone" during sepsis. J Thorac Dis. 2020;12(Suppl 1):S84-8.

32- Kim S, Karasuyama H, Lopez AF, Ouyang W, Li X, Le Gros G, Min B. IL-4 derived from non-T cells induces basophil-and IL-3-independent Th2 immune responses. Immune Netw. 2013;13(6):249-56.

33- Erol N, Saglam L, Saglam YS, Erol HS, Altun S, Aktas MS, et al. The protection potential of antioxidant vitamins against acute respiratory distress syndrome: A rat trial. Inflammation. 2019;42(5):1585-94.

34- Boonstra A, Barrat FJ, Crain C, Heath VL, Savelkoul HF, O'Garra A. 1alpha,25-Dihydroxyvitamin d3 has a direct effect on naive CD4(+) T cells to enhance the development of Th2 cells. J Immunol. 2001;167(9):4974-80.

35- Telcian AG, Zdrenghea MT, Edwards MR, Laza-Stanca V, Mallia P, Johnston SL, et al. Vitamin D increases the antiviral activity of bronchial epithelial cells in vitro. Antiviral Res. 2017;137:93-101.

36- Sims AC, Tilton SC, Menachery VD, Gralinski LE, Schäfer A, Matzke MM, et al. Release of severe acute respiratory syndrome coronavirus nuclear import block enhances host transcription in human lung cells. J Virol. 2013;87(7):3885-902.

37- Schottker B, Jorde R, Peasey A, Thorand B, Jansen EH, Groot L, et al. Vitamin D and mortality: Meta-analysis of individual participant data from a large consortium of cohort studies from Europe and the United States. BMJ. 2014;348:g3656.

38- Antico A, Tampoia M, Tozzoli R, Bizzaro N. Can supplementation with vitamin $\mathrm{D}$ reduce the risk or modify the course of autoimmune diseases? A systematic review of the literature. Autoimmun Rev. 2012;12(2):127-36.

39- Lee GY, Han SN. The role of vitamin E in immunity. Nutrients. 2018;10(11):1614.

40- Han SN, Wu D, Ha WK, Beharka A, Smith DE, Bender $\mathrm{BS}$, et al. Vitamin E supplementation increases T helper 1 cytokine production in old mice infected with influenza virus. Immunology. 2000;100(4):487-93.
6- Beck MA, Levander OA. Host nutritional status and its effect on a viral pathogen. J Infect Dis. 2000;182 Suppl 1:S93-6.

7- Chan NY, Ebi KL, Smith F, Wilson TF, Smith AE. An integrated assessment framework for climate change and infectious diseases. Environ Health Perspect. 1999;107(5):329-37.

8- Wei J, Hansen A, Zhang Y, Li H, Liu Q, Sun Y, et al. The impact of climate change on infectious disease transmission: Perceptions of CDC health professionals in Shanxi Province, China. PLoS One. 2014;9(10):e109476. 9- Lorentzen HF, Benfield T, Stisen S, Rahbek C. COVID-19 is possibly a consequence of the anthropogenic biodiversity crisis and climate changes. Dan Med J. 2020;67(5):A205025.

10- Chionh YT, Cui J, Koh J, Mendenhall IH, Ng JHJ, Low D, et al. High basal heat-shock protein expression in bats confers resistance to cellular heat/oxidative stress. Cell Stress Chaperones. 2019;24(4):835-49.

11- Bell JE, Brown CL, Conlon K, Herring S, Kunkel KE, Lawrimore J, et al. Changes in extreme events and the potential impacts on human health. J Air Waste Manag Assoc. 2018;68(4):265-87.

12- Wang C, Linderholm HW, Song Y, Wang F, Liu Y, Tian $\mathrm{J}$, et al. Impacts of drought on maize and soybean production in Northeast China During the past five decades. Int J Environ Res Public Health. 2020;17(7):2459.

13- Klenert D, Funke F, Mattauch L, O'Callaghan B. Five lessons from COVID-19 for advancing climate change mitigation. Environ Resour Econ. 2020;76:751-78.

14- Wheeler T, Von Braun J. Climate change impacts on global food security. Science. 2013;341(6145):508-13.

15- Beck MA, Matthews CC. Micronutrients and host resistance to viral infection. Proc Nutr Soc. 2000;59(4):581-5.

16- Tirado MC, Crahay P, Mahy L, Zanev C, Neira M, Msangi S, et al. Climate change and nutrition: Creating a climate for nutrition security. Food Nutr Bull. 2013;34(4):533-47.

17- Statista.com [Internet]. New York: Statista; 2020 [Cited 2020 May 9]. Available from: https://www.statista.com

18- Ferrari D, Lombardi G, Strollo M, Pontillo M, Motta A, Locatelli M. Association between solar ultraviolet doses and vitamin D clinical routine data in European midlatitude population between 2006 and 2018. Photochem Photobiol Sci. 2019;18(11):2696-706.

19- Grant WB, Giovannucci E. The possible roles of solar ultraviolet- $B$ radiation and vitamin $D$ in reducing casefatality rates from the 1918-1919 influenza pandemic in the United States. Dermatoendocrinol. 2009;1(4):215-9. 20- Mawson AR. Role of fat-soluble vitamins A and D in the pathogenesis of influenza: A new perspective. ISRN Infect Dis. 2013;246737.

21- Huang Z, Liu Y, Qi G, Brand D, Zheng SG. Role of vitamin $A$ in the immune system. J Clin Med. 2018;7(9):258.

22- Villamor E, Fawzi WW. Effects of vitamin a supplementation on immune responses and correlation with clinical outcomes. Clin Microbiol Rev. 2005;18(3):446-64.

23- Chan JF, Lau SK, To KK, Cheng VC, Woo PC, Yuen KY. Middle East respiratory syndrome coronavirus: Another zoonotic betacoronavirus causing SARS-like disease. Clin 
harmony to reduce the risk of infection. Nutrients. 2020;12(1):236.

55- Percival SS. Copper and immunity. Am J Clin Nutr. 1998;67(5):1064S-8S.

56- Borkow G, Lara HH, Covington CY, Nyamathi A, Gabbay J. Deactivation of human immunodeficiency virus type 1 in medium by copper oxide-containing filters. Antimicrob Agent Chemother. 2008;52(2):518-25.

57- Warnes SL, Little ZR, Keevil CW. Human coronavirus 229E remains infectious on common touch surface materials. mBio. 2015;6(6).

58- Bilal MY, Dambaeva S, Kwak-Kim J, Gilman-Sachs A Beaman KD. A role for iodide and thyroglobulin in modulating the function of human immune cells. Front Immunol. 2017;8:1573.

59- Brown-Grant K. Extrathyroidal iodide concentrating mechanisms. Physiol Rev. 1961;41(1):189-213.

60- Fischer AJ, Lennemann NJ, Krishnamurthy S, Pócza P, Durairaj L, Launspach JL, et al. Enhancement of respiratory mucosal antiviral defenses by the oxidation of iodide. Am J Respir Cell Mol Biol. 2011;45(4):874-81.

61- Eggers M, Koburger-Janssen T, Eickmann M, Zorn J. In vitro bactericidal and virucidal efficacy of povidoneiodine gargle/mouthwash against respiratory and oral tract pathogens. Infect Dis Ther. 2018;7(2):249-59.

62- Schmoranzer F, Fuchs N, Markolin G, Carlin E, Sakr L, Sommeregger $\mathrm{U}$. Influence of a complex micronutrient supplement on the immune status of elderly individuals. Int J Vitam Nutr Res. 2009;79(5-6):308-18.

63- Aluisio AR, Perera SM, Yam D, Garbern S, Peters JL, Abel L, et al. Vitamin A supplementation was associated with reduced mortality in patients with Ebola virus disease during the West African outbreak. J Nutr. 2019;149(10):1757-65.

64- Karadima V, Kraniotou C, Bellos G, Tsangaris GT. Drug-micronutrient interactions: Food for thought and thought for action. EPMA J. 2016;7(1):10.

65- Barchitta M, Quattrocchi A, Maugeri A, La Rosa MC, La Mastra C, Sessa L, et al. Antibiotic consumption and resistance during a 3-year period in Sicily, Southern Italy. Int J Environ Res Public Health. 2019;16(13):2253.

66- Watkins H, Conner D, Thierfelder L, Jarcho JA, MacRae C, McKenna WJ, et al. Mutations in the cardiac myosin binding protein-C gene on chromosome 11 cause familial hypertrophic cardiomyopathy. Nat Genet. 1995;11(4):434-7. 41- Leshchinsky TV, Klasing KC. Relationship between the level of dietary vitamin $\mathrm{E}$ and the immune response of broiler chickens. Poult Sci. 2001;80(11):1590-9.

42- Jarosz M, Olbert M, Wyszogrodzka G, Młyniec K, Librowski T. Antioxidant and anti-inflammatory effects of zinc. Zinc-dependent NF- $\mathrm{B}$ signaling. Inflammopharmacology. 2017;25(1):11-24.

43- Meydani SN, Barnett JB, Dallal GE, Fine BC, Jacques PF, Leka LS, et al. Serum zinc and pneumonia in nursing home elderly. Am J Clin Nutr. 2007;86(4):1167-73.

44- Hao W, Wojdyla JA, Zhao R, Han R, Das R, Zlatev I, et al. Crystal structure of Middle East respiratory syndrome coronavirus helicase. PLoS Pathog. 2017;13(6):e1006474.

45- Gill H, Walker G. Selenium, immune function and resistance to viral infections. Nutr Diet. 2008;65(s3):S417.

46- Harthill M. Review: Micronutrient selenium deficiency influences evolution of some viral infectious diseases. Biol Trace Elem Res. 2011;143(3):1325-36.

47- Beck MA, Esworthy RS, Ho YS, Chu FF. Glutathione peroxidase protects mice from viral-induced myocarditis. FASEB J. 1998;12(12):1143-9.

48- Broome CS, McArdle F, Kyle JA, Andrews F, Lowe NM, Hart CA, et al. An increase in selenium intake improves immune function and poliovirus handling in adults with marginal selenium status. Am J Clin Nutr. 2004;80(1):154-62.

49- Ekiz C, Agaoglu L, Karakas Z, Gurel N, Yalcin I. The effect of iron deficiency anemia on the function of the immune system. Hematol J. 2005;5(7):579-83.

50- Deugnier Y, Battistelli D, Jouanolle H, Guyader D, Gueguen M, Loreal $\mathrm{O}$, et al. Hepatitis B virus infection markers in genetic haemochromatosis: A study of 272 patients. J Hepatol. 1991;13(3):286-90.

51- Agoro R, Taleb M, Quesniaux VF, Mura C. Cell iron status influences macrophage polarization. PLoS One. 2018;13(5):e0196921.

52- Wang H, Li Z, Niu J, Xu Y, Ma L, Lu A, et al. Antiviral effects of ferric ammonium citrate. Cell Discov. 2018;4:14. 53- Kumar R, Nayak M, Sahoo GC, Pandey K, Sarkar MC, Ansari $Y$, et al. Iron oxide nanoparticles based antiviral activity of H1N1 influenza A virus. J Infect Chemother. 2019;25(5):325-9.

54- Gombart AF, Pierre A, Maggini S. A review of micronutrients and the immune System-Working in 